\title{
Impacts of long-term land-use changes on herd size and mobility among pastoral households in Amboseli ecosystem, Kenya

\author{
Kennedy Sakimba Kimiti ${ }^{12^{*}}$, David Western², Judith Syombua Mbau and Oliver Vivian Wasonga ${ }^{1}$
}

\begin{abstract}
Introduction: Long-term changes in rangeland ecosystems of the world have impacted on the livestock production, a key livelihood strategy in these areas. This paper presents perceptions of the pastoral community on the dynamics of pastoral livelihoods under three land-use types namely nomadic, semi-nomadic, and sedentary in Amboseli ecosystem located in southern Kenya. Structured questionnaire was used to collect data concerning household livestock herds, perceived livestock trends and their causes, importance of migration, sedentarization, and land subdivision, and were administered to respondents randomly selected from the three land-use types.
\end{abstract}

Results: The study shows that the livestock herd size was higher in nomadic (117.1) and lower in sedentary (56.6) land-use site. The majority of the respondents in nomadic (79\%), semi-nomadic (73\%), and sedentary (64\%) reported a declining trend in household herd size. The declines were mostly attributed to recurrent droughts and loss of grazing lands.

Conclusions: Pastoralism remains an important livelihood strategy to majority of households in the study area; therefore, to achieve sustainable livelihood strategies, grazing lands should be maintained.

Keywords: Herd mobility, Household livestock trends, Rangeland changes, Community views

\section{Introduction}

Land-use land-cover change (LULCC) in rangeland ecosystems has been a major global concern to conservationists and researchers globally (Msoffe et al. 2011). The rangelands covering nearly half of the total land surface in Africa support extensive livestock production and wildlife conservation (Nyariki et al. 2009; Kaimba et al. 2011; Nkedianye et al. 2011; Bekele and Kabede 2014). Pastoralism, characterized by herd mobility to track grazing water resources in space and time, has been the dominant livelihood strategy in these ecosystems, supporting millions of people (Nkedianye et al. 2011; Tefera 2014; Berhanu and Beyene 2015). In East Africa, pastoral societies practicing various forms of pastoralism occupy $70 \%$ of total land in Kenya, 50\% in Tanzania, and 40\% in Uganda (Reda 2012). Amboseli ecosystem in Kajiado County is part of the arid and semi-arid lands (ASAL) that constitute the $70 \%$ of

\footnotetext{
* Correspondence: sakimbakim@gmail.com

'Department of Land Resource Management and Agricultural Technology,

University of Nairobi, P. O Box 30197, Nairobi, Kenya

${ }^{2}$ Amboseli Conservation Project, P. O Box 15289, Nairobi 00509, Kenya
}

Kenya's land mass supporting extensive traditional livestock production and wildlife conservation.

Major changes have been observed in key pastoral resources in Amboseli ecosystem in the past three decades (Kioko and Okello 2010; Nyamasyo and Kihima 2014). The long-term changes that include declining proportions of wet and dry season grazing reserves, woody vegetation, and variety of pastures have had negative impacts on pastoralism and wildlife conservation in Amboseli area (Kioko and Okello 2010; Western et al. 2015). The resource dynamics have consequently impacted on the livestock base as a key pastoral economy which traditionally provided multiple functions. The fundamental functions of pastoral herds include regular provision of food in form of meat, milk, and blood, as well as cash income, measure of exchange in terms of dowry, compensation of injured persons during raid, symbol of wealth and prosperity and security against droughts, disease outbreaks, and other rangeland calamities (Nyariki et al. 2009; Kaimba et al. 2011; Opiyo et al. 2011; Schilling et al. 2012). 
Declining livestock production and productivity in most pastoral areas is partly due to the expansion of cultivation into grazing areas gradually converting the savanna grassland ecosystems suitable for domestic and wild animal grazing (Olson et al. 2004). In recent decades, the wetlands in Amboseli ecosystem which acted as dry season refuges and were owned communally have notably experienced dramatic changes in land tenure consequently impacting on land-use and vegetation cover (Msoffe et al. 2011; Nyamasyo and Kihima 2014). The changes in land tenure have caused changes in land-use practice in Amboseli ecosystem (Okello 2012) reducing the vast grazing land. The changing land ownership influences the rate and pace at which land use changes in the study area (Noe 2003).

Sedentarization and range fragmentation due to changing land tenure have led to restricted livestock mobility resulting in all season grazing that exerts pressure in certain grazing patches thereby leading to range degradation. Loss of livestock due to factors such as declining land productivity, shrinking grazing areas, restricted movements, and the recurrent droughts has resulted in increased poverty and vulnerability of pastoral households and erosion of their resilience to future shocks (Fratkin 2008; Groom and Western 2013; Kirwa et al. 2012; Moyo et al. 2013).

This study was carried out to assess the perceptions of local communities on the effects of resource changes on livestock herd sizes and their mobility based on the changing land tenure system in Amboseli ecosystem.
The study compared individual household herd sizes in three land-use sites which included sedentary land-use site where land had been subdivided, semi nomadic (partial subdivision) and nomadic (no subdivision). The results of this study are expected to increase understanding on the impacts of the rangeland change dynamics on livestock as key pastoral economy, the most viable land-use option beside wildlife conservation in the arid and semi-arid rangeland ecosystems.

\section{Methods}

\section{Study area}

The study was conducted in Amboseli ecosystem (Fig. 1) located on the Kenyan-Tanzania border, covering the $388 \mathrm{~km}^{2}$ Amboseli National Park and surrounding Maasai group ranches (Western et al. 2015). The national park, covering $7 \%$ of the ecosystem, serves as a dry season concentration area for livestock and wildlife due to the series of swamps within (Kipkeu et al. 2014). The area experiences bimodal rainfall with peaks from March to May and October to December (Campbell et al. 2005), and drought is a common feature in the area. The ecosystem is semiarid, which is suitable for livestock grazing, wildlife conservation, and tourism (Kioko et al. 2012). The expansive lowlands of the Amboseli savannah are of low productivity with high agricultural potential on the high slopes of Mt. Kilimanjaro and the expansive hills (Campbell et al. 2003).

Amboseli ecosystem has experienced drastic changes in land use and land cover over the last four decades,

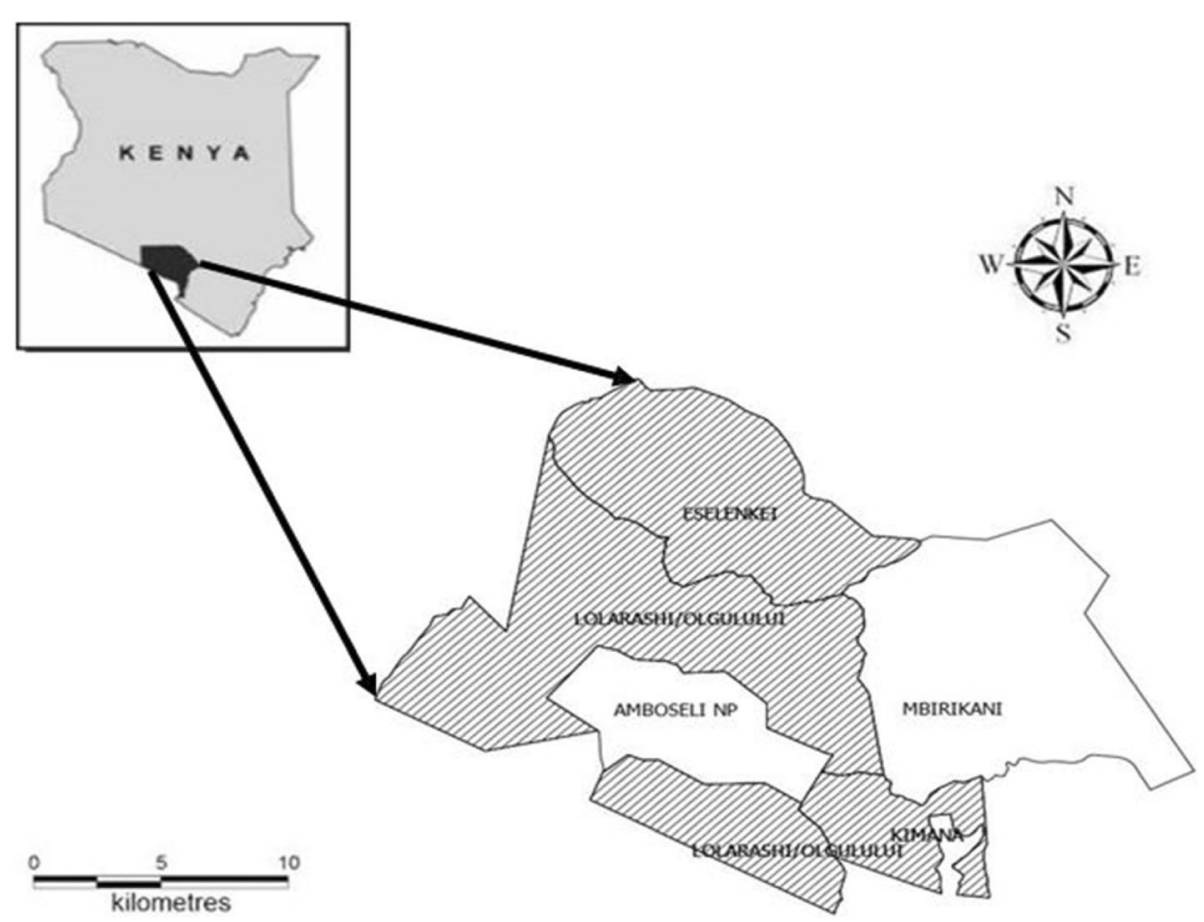

Fig. 1 The Amboseli ecosystem (Amboseli National Park and surrounding group ranches) 
among them, changes in habitats, woodland, declining grazing areas, and loss of land productivity and desirable forage species (Campbell et al. 2003; Kioko and Okello 2010; Western and Nightingale 2003; Western and Maitumo 2004; Western 2007, Western et al. 2015). The expansion of cultivation into wetlands which acted as dry season grazing areas has been observed in the ecosystem over the decades thereby impacting negatively on the livestock economy (Campbell et al. 2003; Kioko and Okello 2010). The Maasai are the dominant community in the area. They mainly practice extensive livestock production on the extensive landscapes, but recently, immigrants from the already overpopulated central highlands of Kenya and neighboring Tanzania have engaged in cultivation in the wetlands in the area (Campbell et al. 2000; Campbell et al. 2003).

\section{Data collection}

The sampling was stratified based on major land-use types as described by Campbell et al. 2003) and proximity to Amboseli National park. Multistage sampling method was used to select the respondents. In the first stage, preliminary surveys and interviews in the study area were used in selecting the study sites, which formed the clusters. The clusters included three land-use sites namely, nomadic (Eselenkei group ranch), semi-nomadic (Olgulului group ranch), and sedentary (Kimana group ranch). Nine villages were randomly selected, three from each land-use site in the second stage. One hundred and twenty respondents from nomadic, 131 from seminomadic, and 83 from the sedentary land-use site were randomly selected for individual interviews in the third stage, making a total of 334 respondents.

Both qualitative and quantitative data were collected through administration of a structured questionnaire to the household heads. The questionnaire was tested during 1 week of pilot study on 30 village members prior to actual study. Four assistant enumerators were trained and equipped with appropriate data collection skills for the study. The administered questionnaire was populated with questions seeking data on livestock herd size, dynamics of livestock production and their management, individual views on significance of migration, and benefits of sedentarization, as well as views on land subdivision and importance of communal land.

\section{Data analyses}

Data collected using the structured questionnaire were subjected to analysis using statistical package for social sciences (SPSS IBM version statistics 19). The data was analyzed to produce frequency tables on the various attributes under investigation. ANOVA test was used to test variability in mean household herd size under different socio-demographic attributes in the three land-use sites under study. Chi-square goodness of fit test was used to determine the significant difference on views among households on importance of pastoral mobility and benefits of settling down by pastoralists from different study sites. Cross tabulation was used to determine the significant difference between households that still migrate, if their herd sizes have changed and causes of the change and if they have recovered since the 2009 drought. The level of significance was tested at $5 \%$.

\section{Results \\ Livestock herd dynamics under different socio- demographic categories}

The mean herd sizes by socio-demographic attributes of the sampled households in the three land-use types are shown in Table 1. Household herd size differed significantly $(P<0.001)$ between the areas with the highest average herd size recorded in nomadic site (117.1) and the lowest in the sedentary site (56.6). Households with heads aged between 46 and 80 years had larger herds in all the study sites with the exception of 56-65 in sedentary with smaller herd size (Table 1). In addition, large households of between 11-15 and 16-20 persons owned larger herds than the smaller households. Herd sizes among respondents under different education levels did not differ significantly $(P=0.189)$ in the study sites. Livestock production remains the main livelihood option in the three land-use sites as shown by the largest average herd size among the other land-use options.

\section{Community views on household herd sizes over the last four decades in the study locations}

The majority of the respondents in the nomadic (79\%), semi-nomadic (73\%), and sedentary (64\%) areas reported a declining trend in household herd sizes over the last four decades (Table 2). Most (nomadic 79\%; seminomadic $73 \%$; sedentary $64 \%$ ) of those who reported a declining trend in herd size attributed it to the loss of grazing lands and the frequent droughts in the study area. The few $(21 \%$ in nomadic, $27 \%$ in semi nomadic, $33 \%$ in sedentary) who reported an increase in household herd size attributed it to either accumulation of more livestock through purchases, as well as rapid herd growths following good pasture years.

There was significant $(p<0.05)$ difference in opinions on whether the household herds have recovered since the 2009 drought or not. Despite the decreasing trends in livestock numbers, majority (59\%) of the households in the nomadic area reported recovery in their herds after the 2009 drought. Most (68\%) of the households in the nomadic area attributed the recovery in livestock numbers to post-drought restocking.

Herd mobility is still being practiced in all the landuse sites but least effective in the sedentary site as 
Table 1 Herd sizes (by tropical livestock unit (TLU)) aggregated by household socio-demographic attributes

\begin{tabular}{|c|c|c|c|c|c|c|}
\hline \multirow[t]{2}{*}{ Variable } & \multirow[t]{2}{*}{ Category } & \multirow{2}{*}{$\begin{array}{l}\text { Nomadic }(n=120) \\
\text { Mean }\end{array}$} & \multirow{2}{*}{$\begin{array}{l}\text { Semi-nomadic }(n=131) \\
\text { Mean }\end{array}$} & Sedentary $(n=83)$ & \multirow[t]{2}{*}{$F$ value } & \multirow[t]{2}{*}{ Sig } \\
\hline & & & & Mean & & \\
\hline Herd size & & 40.8 & 25.0 & 22.9 & 9.06 & $P<0.001$ \\
\hline \multirow[t]{6}{*}{ Age } & $19-25$ & - & 40.6 & 8.5 & 2.64 & $P=0.023$ \\
\hline & $26-35$ & 25.7 & 15.6 & 17.5 & & \\
\hline & $36-45$ & 28.2 & 13.0 & 27.4 & & \\
\hline & $46-55$ & 39.2 & 31.8 & 36.3 & & \\
\hline & $56-65$ & 60.1 & 38.0 & 11.5 & & \\
\hline & $70-80$ & 49.4 & 23.7 & 21.7 & & \\
\hline \multirow[t]{4}{*}{ Household size } & $1-5$ & 45.5 & 20.0 & 20.5 & 8.23 & $P<0.001$ \\
\hline & $6-10$ & 29.6 & 20.6 & 17.7 & & \\
\hline & $11-15$ & 46.8 & 43.8 & 30.6 & & \\
\hline & $16-20$ & 57.4 & 42.0 & 51.2 & & \\
\hline \multirow[t]{4}{*}{ Education level } & None & 41.2 & 24.1 & 19.6 & 1.602 & $P=0.189$ \\
\hline & Primary & 36.9 & 25.9 & 39.6 & & \\
\hline & Secondary & 29.1 & 55.4 & 53.6 & & \\
\hline & Tertiary & - & - & 6.4 & & \\
\hline \multirow[t]{6}{*}{ Main livelihood } & Crop cultivation & - & - & 20.6 & 1.882 & $P=0.083$ \\
\hline & Formal employment & - & 4.7 & 13.0 & & \\
\hline & Informal employment & - & - & 2 & & \\
\hline & Livestock & 40.8 & 34.1 & 28.0 & & \\
\hline & Small businesses & & 5.4 & 8.6 & & \\
\hline & Tourism & & 12.4 & 9.7 & & \\
\hline
\end{tabular}

Note: Figures are presented in TLU where $1 \mathrm{TLU}$ is equivalent to $250 \mathrm{~kg}$ live weight, a cow $=1 \mathrm{TLU}$, a calf $=0.4 \mathrm{TLU}, \mathrm{a}$ shoat $=0.11 \mathrm{TLU}$, lambs $=0.05 \mathrm{TLU}, \mathrm{kids}=$ 0.04 TLU, donkeys = 0.5 TLU: Source: Kristjanson et al. 2002; Wilson 2003

reported by $39 \%$ of the respondents. The majority (48\% in nomadic, $61 \%$ in semi-nomadic, $54 \%$ in sedentary) of those who reported the changing mobility pattern attributed it to increased settlements, loss of land productivity, changing weather pattern, and restricted pastoral mobility. Accessing range resources (67\%), escaping drought (13\%), and evading disease outbreaks (10\%) were the most reported benefits of migration perceived by the respondents as shown in Table 3 . The perceived benefits of sedentarization differed significantly with the majority (44\%) of the respondents mentioning ease of accessing social services and amenities. Other significance of settling down reported were ease of looking after young herds and tending to sick individuals (23\%) and promoting development of marginal areas (18\%). Respondents also indicated that when they settle, households are able to diversify their livelihood sources by engaging in various economic activities, and conflict over resources that do occur as they move with their herds beyond their territories is minimized.

Table 4 shows that the community views from the three land-use sites did not differ significantly on effects of land subdivision on livestock herd size $\left(\chi^{2}=1.133, \mathrm{df}=2, p=\right.$ 0.567 ). A significant proportion ( $95 \%$ nomadic, $95 \%$ semi- nomadic; 98\% sedentary) of the respondents (Table 4) noted that land subdivision has affected the household herd sizes in the study area, with the majority $(93,96$, and $88 \%$ in nomadic, semi-nomadic, and sedentary respectively) reporting a declining effect on their trend. Only in the nomadic land-use site did a majority (57\%) prefer the group ranch land ownership to the individual ownership, which was highly preferred in both sedentary $(60 \%)$ and semi-nomadic $(60 \%)$ sites.

\section{Suggested ways of restoring livestock production as key pastoral economy}

Restoring or retaining traditional livestock production practices was supported by most $(70 \%, n=234)$ of the respondents. The customary livestock and range management practices that needed to be restored varied significantly $\left(\chi^{2}=151.69, \mathrm{df}=5, p<0.001\right)$. The practices included herd mobility (38\%), maintaining communal land tenure system (32\%), kinship ties and relationships $(11 \%)$, keeping large herd sizes (9\%), pasture management $(6 \%)$, and reservation of dry season grazing refuges (4\%). Those who opposed the restoration of customary practices perceived them as outdated practices (53\%), 
Table 2 Views on herd size dynamics and management practices over the last four decades as perceived by the community

\begin{tabular}{|c|c|c|c|c|c|}
\hline \multirow[t]{2}{*}{ Issue } & \multirow[t]{2}{*}{ Response } & \multicolumn{3}{|c|}{ Frequency of respondents } & \multirow{2}{*}{$\begin{array}{l}\text { Chi-square cross } \\
\text { tabulation test }\end{array}$} \\
\hline & & Nomadic & Semi-nomadic & Sedentary & \\
\hline \multirow[t]{2}{*}{ Has household herd size changed? } & Yes & $113(94)$ & $118(90)$ & $78(94)$ & \multirow{2}{*}{$\begin{array}{l}X^{2}=1.854 \\
\mathrm{df}=2 \\
p=0.396\end{array}$} \\
\hline & No & $7(6)$ & $13(10)$ & $5(6)$ & \\
\hline \multirow{2}{*}{$\begin{array}{l}\text { Which is the perceived direction of } \\
\text { change in herd size }\end{array}$} & Increased & $24(21)$ & $32(27)$ & $26(33)$ & \multirow{2}{*}{$\begin{array}{l}x^{2}=3.496 \\
d f=2 \\
p=0.174\end{array}$} \\
\hline & Decreased & $89(79)$ & $86(73)$ & $52(64)$ & \\
\hline \multirow[t]{3}{*}{ Reasons for increase? } & Born & $3(13)$ & $18(56)$ & $13(50)$ & \multirow{3}{*}{$\begin{array}{l}x^{2}=16 \\
d f=4 \\
p=0.003\end{array}$} \\
\hline & Bought & $16(66)$ & $12(38)$ & $13(50)$ & \\
\hline & Good pastures & $5(21)$ & $2(6)$ & 0 & \\
\hline \multirow[t]{5}{*}{ Reasons for decrease? } & Frequent drought & $74(83)$ & $60(70)$ & $26(50)$ & \multirow{5}{*}{$\begin{array}{l}x 2=27.842 \\
d f=8 \\
p<0.001\end{array}$} \\
\hline & Investing on livestock & $6(7)$ & $1(1)$ & $3(6)$ & \\
\hline & Livestock diseases & $2(2)$ & $10(12)$ & $6(12)$ & \\
\hline & Loss of grazing land & $5(5)$ & $7(8)$ & $11(21)$ & \\
\hline & Poverty & $2(2)$ & $8(9)$ & $6(11)$ & \\
\hline \multirow[t]{2}{*}{ Has livestock recovered since 2009} & Yes & $71(59)$ & $43(33)$ & $41(49)$ & \multirow{2}{*}{$\begin{array}{l}x 2=17.871 \\
\mathrm{df}=2 \\
p<0.001\end{array}$} \\
\hline & No & $49(41)$ & $88(67)$ & $42(51)$ & \\
\hline \multirow{4}{*}{$\begin{array}{l}\text { How household livestock has } \\
\text { recovered since } 2009 \text { drought }\end{array}$} & Born & $11(15)$ & $19(44)$ & $20(49)$ & \multirow{4}{*}{$\begin{array}{l}x 2=14.725 \\
\mathrm{df}=3 \\
p<0.001\end{array}$} \\
\hline & Gift & $3(4)$ & & $1(2)$ & \\
\hline & Good pastures & $9(13)$ & $9(21)$ & $2(5)$ & \\
\hline & Bought & $48(68)$ & $15(35)$ & $18(44)$ & \\
\hline \multirow{6}{*}{$\begin{array}{l}\text { Reasons why livestock have not } \\
\text { recovered since } 2009 \text { drought? }\end{array}$} & Investing on livestock & 0 & $5(6)$ & $4(10)$ & \multirow{6}{*}{$\begin{array}{l}x 2=20.052 \\
d f=10 \\
p=0.029\end{array}$} \\
\hline & Lack of herding labor & $7(14)$ & $7(8)$ & $3(7)$ & \\
\hline & Livestock diseases & $7(14)$ & $7(7)$ & $8(19)$ & \\
\hline & Loss of grazing land & $18(38)$ & $33(38)$ & $6(14)$ & \\
\hline & Poverty & $2(4)$ & $5(6)$ & $7(17)$ & \\
\hline & Recurrent droughts & $15(30)$ & $31(35)$ & $14(33)$ & \\
\hline \multirow[t]{2}{*}{ Does household practice herd mobility? } & Yes & $113(98)$ & $113(90)$ & $18(24)$ & \multirow{2}{*}{$\begin{array}{l}x 2=24.056 \\
d f=2 \\
p<0.001\end{array}$} \\
\hline & No & $2(2)$ & $13(10)$ & $57(76)$ & \\
\hline \multirow[t]{2}{*}{ Is mobility still effective? } & Yes & $105(88)$ & $105(80)$ & $32(39)$ & \multirow{2}{*}{$\begin{array}{l}x 2=20.01 \\
d f=2 \\
p<0.001\end{array}$} \\
\hline & No & $15(12)$ & $26(20)$ & $51(61)$ & \\
\hline \multirow[t]{4}{*}{ Reasons why herd mobility is ineffective? } & Lack of herding labor & $2(13)$ & $2(8)$ & $5(16)$ & \multirow{4}{*}{$\begin{array}{l}x 2=8.784 \\
d f=6 \\
p=0.186\end{array}$} \\
\hline & Loss of land productivity & $11(74)$ & $19(73)$ & $13(41)$ & \\
\hline & Overgrazing & 0 & $1(4)$ & $2(6)$ & \\
\hline & Restricted movement & $2(13)$ & $4(15)$ & $12(37)$ & \\
\hline \multirow[t]{2}{*}{ Has migration pattern changed? } & Yes & $58(48)$ & $80(61)$ & $45(54)$ & $x 2=4.115$ \\
\hline & No & $62(52)$ & $51(39)$ & $38(46)$ & $\begin{array}{l}\mathrm{dT}=2 \\
p=0.128\end{array}$ \\
\hline What are the perceived causes of & Changed pastoral lifestyle & 0 & $2(4)$ & $9(23)$ & $x 2=60.379$ \\
\hline & Changed weather pattern & $10(16)$ & $19(37)$ & $2(5)$ & $\begin{array}{l}\mathrm{dt}=12 \\
p<0.001\end{array}$ \\
\hline & Increased settlement & $20(32)$ & $8(16)$ & $5(13)$ & \\
\hline & Lack of herding labor & $10(16)$ & $3(6)$ & $1(3)$ & \\
\hline & Loss of land productivity & $11(18)$ & $10(20)$ & $9(24)$ & \\
\hline & Population increase & $5(8)$ & $8(15)$ & $1(3)$ & \\
\hline & Restricted movement & $6(10)$ & $1(2)$ & $11(29)$ & \\
\hline
\end{tabular}


Table $\mathbf{3}$ Importance of migration and sedentarization as perceived by the community

\begin{tabular}{|c|c|c|c|}
\hline Issue & Benefit & $\begin{array}{l}\text { Frequency of } \\
\text { respondents }\end{array}$ & $\begin{array}{l}\text { Chi-square } \\
\text { goodness of fit }\end{array}$ \\
\hline \multirow[t]{5}{*}{$\begin{array}{l}\text { Benefits of } \\
\text { migration }\end{array}$} & $\begin{array}{l}\text { Access variable } \\
\text { resources }\end{array}$ & $224(67)$ & $x 2=474.71$ \\
\hline & $\begin{array}{l}\text { Escape disease } \\
\text { outbreak }\end{array}$ & $35(10)$ & $d f=4$ \\
\hline & Escape drought & $42(13)$ & $p<0.001$ \\
\hline & $\begin{array}{l}\text { Evade livestock } \\
\text { congestion }\end{array}$ & $4(1)$ & \\
\hline & $\begin{array}{l}\text { Improves livestock } \\
\text { production }\end{array}$ & $29(9)$ & \\
\hline \multirow[t]{5}{*}{$\begin{array}{l}\text { Benefits of } \\
\text { settling down }\end{array}$} & $\begin{array}{l}\text { Better access to } \\
\text { social amenities }\end{array}$ & $146(44)$ & $x^{2}=154.05$ \\
\hline & $\begin{array}{l}\text { Diversifying } \\
\text { household economy }\end{array}$ & $11(3)$ & $d f=4$ \\
\hline & $\begin{array}{l}\text { Attending sick and } \\
\text { young livestock }\end{array}$ & $78(23)$ & $p<0.001$ \\
\hline & $\begin{array}{l}\text { Boosts development } \\
\text { of an area }\end{array}$ & $59(18)$ & \\
\hline & Reduces conflicts & $40(12)$ & \\
\hline
\end{tabular}

contribute to slow development (20\%), modernization and development (14\%), and are not sustainable (13\%).

Current range management system in the area has resulted in decline in rangeland condition as noted by many (62\%) respondents. Opinions whether there existed any practiced management system in the study sites differed significantly $\left(\chi^{2}=8.35, \mathrm{df}=2, p<\right.$ $0.001)$. Majority of respondents in both nomadic (64\%) and semi nomadic (63\%) land-use sites noted presence of a range management system in their area and only $46 \%$ in the sedentary land-use area. The majority (79\%) of those who mentioned absence of a rangeland management system would support implementation of the conventional system in their area. Views on the exact approach varied significantly $\left(\chi^{2}=\right.$ 86.58, $\mathrm{df}=5, p<0.001)$ among the respondents. The mentioned options for the perceived designation of the rangeland ecosystem of the study area included partitioning of conservation areas (32\%), dry season grazing areas or forage banks (22\%), migratory routes (15\%), cultivation areas (14\%), development areas (12\%), and settlement areas (5\%).

The majority of the respondents (90\%) would support establishment of information center to share and access useful information. The information they would prefer included information on livestock husbandry (55\%), businesses (39\%), crop cultivation (20\%), conservation $(19 \%)$, tourism $(5 \%)$, and pasture production $(4 \%)$.

Most $(71 \%)$ of the respondents noted that the rangeland resource governance system has changed over time and no longer able to regulate resource use. Customary resource governance is no longer effective because of poor leadership attributed to the election process that was reported to ignore leadership attributes.

\section{Discussion}

It is apparent that many rangeland resources have changed over time consequently affecting livestock numbers in the three land-use sites as reported by the respondents in this study. Livestock rearing which is the main livelihood strategy in Amboseli ecosystem has seen drastic decline due to the changes in rangeland resources evident in the declining sizes of household herds reported by majority of respondents. These trends were mainly attributed to reduction in grazing areas as a result in increase in settlements and corresponding human population growth, expansion of crop farming, and the frequent recurrent droughts in the region. These factors are also known to restrict livestock mobility, which is a key strategy used by pastoralists to exploit resources in environments that are highly variable in space and time. The community perceptions of the declining livestock herd size are similar to those reported by Kioko and Okello (2010). The authors attributed the declines to increase in land uses at the expense of grazing land among them, expansion of cultivation areas, clearing of land for settlement leading to loss of vegetation in the area. Tilahun et al. (2016) also observed that livestock holdings on average was higher in non-intervened than

Table 4 Views of respondents on effects of land subdivision and tenure preference

\begin{tabular}{|c|c|c|c|c|c|}
\hline \multirow[t]{2}{*}{ Issue } & \multirow[t]{2}{*}{ Response } & \multicolumn{3}{|c|}{ Percentages of respondents } & \multirow{2}{*}{$\begin{array}{l}\text { Chi-square cross } \\
\text { tabulation test }\end{array}$} \\
\hline & & Nomadic $(n=120)$ & Semi-nomadic $(n=131)$ & Sedentary $(n=83)$ & \\
\hline \multirow{2}{*}{$\begin{array}{l}\text { If subdivision affects } \\
\text { household herd size }\end{array}$} & Yes & $114(95)$ & $124(95)$ & $81(98)$ & \multirow{2}{*}{$\begin{array}{l}x 2=1.133 \\
d f=2 \\
p=0.567\end{array}$} \\
\hline & No & $6(5)$ & $7(5)$ & $2(2)$ & \\
\hline \multirow{2}{*}{$\begin{array}{l}\text { Effects of subdivision } \\
\text { on household herd size }\end{array}$} & Increase & $8(7)$ & $5(4)$ & $10(12)$ & \multirow{2}{*}{$\begin{array}{l}x 2=229.79 \\
d f=2 \\
p<0.001\end{array}$} \\
\hline & Decrease & $106(93)$ & $119(96)$ & $71(88)$ & \\
\hline \multirow{2}{*}{$\begin{array}{l}\text { Land tenure of } \\
\text { preference }\end{array}$} & Group ranch & $68(57)$ & $53(40)$ & $33(40)$ & \multirow{2}{*}{$\begin{array}{l}x 2=8.413 \\
\mathrm{df}=2 \\
p=0.014\end{array}$} \\
\hline & Private land & $52(43)$ & $78(60)$ & $50(60)$ & \\
\hline
\end{tabular}


intervened areas of Afar region of Ethiopia. The authors partly attributed the declines in herd sizes to shrinkage in grazing lands and the recurrent droughts similar to observations noted in this study.

The nomadic land-use site still supports large livestock numbers and herd mobility as compared to those which have been subdivided. The nomadic pastoral system maintains mobile, large-scale livestock movement and avoids heavy grazing pressure on grasslands as opposed to the semi-nomadic and sedentary systems (Groom and Western 2013; Western et al. 2009). Pastoral mobility on communally owned land allows moderate and continuous grazing supporting large herds compared to permanent settlement that results in continuous grazing on a small piece of land which consequently leads to overgrazing and land degradation. The result is decline in grazing areas and available forage for livestock.

The decline in grazing areas has also partly been contributed by expansion of crop cultivation on productive wetlands and loss of range productivity. The observed trends have led to decline in vegetation resources and consequently biodiversity in the study area. Coupled with rising human population growth, overexploitation of range resources and restricted pastoral mobility, overgrazing in the fragmented rangelands, have led to decline in land productivity as evident in low biomass production per unit of rainfall (Western et al. 2015). Severe grazing by livestock due to restricted mobility results in changes in biodiversity, as well as decline in range productivity, land carrying capacity, its soil fertility, and consequently land degradation and desertification (Nyariki et al. 2009). Similar trend has been observed in the Masai Mara ecosystem (Nyariki et al. 2009), whereby the recent shift from nomadic to semi-nomadic to pure cultivation has negatively impacted the livestock sector due to changes in vegetation resources.

Groom and Western (2013) reported adverse impacts of permanent settlements on pastoral rangelands. The authors indicate that settlements lead to reduction in forage resources, lower grass biomass, and lower grass recovery after prolonged dry periods and reduced seasonal movement of livestock, all which work in concert to undermine range productivity. In their model, Boone et al. (2005) showed reduced livestock numbers in fragmented landscapes as a result of curtailed mobility. As reported in areas where nomadic pastoralism dominates, mobility allows sustainable utilization of rangelands and supports large herds. These findings are consistent with those of Kioko and Okello (2010), where the community attributed the declining livestock numbers to subdivision of pastoral land and pasture scarcity.

Subdivision of communal pastoral lands started with group ranch demarcations in 1968, which restricted herd movements in the pastoral areas. The group ranches were established under the Land (Group representative) Act Cap. 287 of the laws of Kenya with the aim of reducing overgrazing in range ecosystems, improving livestock production, and increasing community awareness on environmental conservation (Nyariki et al. 2009). The intended objectives were not met as problems of land degradation escalated, thereby further undermining pastoral livestock production. This later led to further government interventions to privatize communal lands intended to better livestock production and meet desired conservation goals.

Privatization of communal rangeland were further encouraged with the intentions of providing health and education services, increasing livestock productivity (Reid et al. 2014), objectives similar to what the respondents of this study opted for. Sedentarization was highlighted to help in taking care of young herds and closely monitoring the sick animals, which would improve pastoral production. Permanent settlements on individual parcels of land and the resulting restricted herd movement lead to land degradation, leading to unsustainable livelihoods and impoverishment of pastoral households.

Given the semi-arid climate of the Amboseli ecosystem, competing land uses such as cultivation are limited to the high potential ranges and require substantial initial investments where irrigation is involved, therefore leaving pastoralism as the main livelihood strategy in the larger areas of the ecosystem. Therefore, utilization of these environments will only remain viable if herd mobility is restored in the changing landscape. Traditional pastoral practices such as keeping large herds, splitting herds during dry periods, and keeping mix herds that utilize the different vegetation resources need to be restored or encouraged. Land subdivision in pastoral areas is inevitable; therefore, the need for interventions to ensure livestock mobility in the fragmented landscapes. One of the ways is to advocate for community land trust that allows land-use zoning to provide areas for conservation, grazing, cultivation, and settlements.

\section{Conclusions}

Long-term changes in range resources in the Amboseli ecosystem have led to decline in size of household herds over the past four decades. The livestock declines were more significant in the sedentary land-use site than in both semi-nomadic and nomadic areas under study. Herd mobility is possible in the nomadic land-use type due to limited competing land uses in the area. Sedentary site and parts of semi-nomadic site have experienced changes in land tenure from traditional communal system to individual ownership. The changes in land reforms has significantly reduced the grazing areas and promoted permanent settlements that have restricted herd mobility 
thereby undermining livestock production in the area. For sustainable livelihoods to be achieved and better food security in the changing rangeland ecosystem in Amboseli, interventions among them forming land trusts that advocate for land-use planning to allow for livestock movement to exploit the variable resources should be encouraged.

\section{Abbreviations}

ANOVA: Analysis of variance; ASAL: Arid and semi-arid land; LULCC: Land-use land-cover change; SPSS: Statistical package for social sciences

\begin{abstract}
Acknowledgements
Many thanks to Amboseli Conservation Project for providing a conducive environment and logistical support for this study. This study was accomplished through the endless efforts of David Maitumo, Paul Kasaine, Samuel Lekanaya, and George Sunte who assisted in data collection. Specia thanks and appreciation also goes to the members of Eselenkei, Olgulului, and Kimana group ranches who provided useful information presented in this study.
\end{abstract}

\section{Funding}

Not applicable.

\section{Availability of data and materials}

Not applicable.

\section{Authors' contributions}

KSK developed the concept, collected and analyzed data, and drafted the manuscript. OWW, DW, and JMS helped in the conception of the research idea and design and made comments on the manuscript. All authors read and approved the final manuscript.

\section{Authors' information}

KSK is a second-year MSc student at the University of Nairobi undertaking Range management, Ecology option.

OWW is a senior lecturer at the Department of Land Resource Management and Agricultural Technology at the University of Nairobi. He is a dryland ecosystem specialist.

DW is a senior researcher at Amboseli Conservation Program, Amboseli ecosystem, Kajiado County. He is a specialist on savannah ecosystems and human ecology.

JMS is a lecturer at the Department of Land Resource Management and Agricultural Technology at the University of Nairobi. She is a rangeland resource management specialist

\section{Ethics approval and consent to participate}

Not applicable.

\section{Consent for publication}

Not applicable.

\section{Competing interests}

The authors declare that they have no competing interest.

\section{Publisher's Note}

Springer Nature remains neutral with regard to jurisdictional claims in published maps and institutional affiliations.

Received: 27 September 2017 Accepted: 15 January 2018 Published online: 02 February 2018

\section{References}

Bekele N, Kabede G (2014) Rangeland degradation and restoration in semi-arid areas of southern Ethiopia: the case study of Borana rangeland. Int J Environ Sci 3(2):94-103

Berhanu W, Beyene F (2015) Climate variability and household adaptation strategies in southern Ehiopia. Sustainability 7:6365-6367
Boone RB, Burnsilver SB, Thornton PK, Worden JS, Galvin KA (2005) Quantifying declines in livestock due to land subdivision. Rangeland Ecol Manage 58:523-532

Campbell DJ, Gichohi H, Mwangi A, Chege L (2000) Land use conflict in Kajiado district, Kenya. Land use policy 17(4):337-348.

Campbell DJ, Gichohi H, Reid R, Mwangi A, Chege L, Sawin T (2003) Interactions between people and wildlife in Southeast Kajiado District, Kenya. LUCID Project, International Livestock Research Institute; 2003.

Campbell DJ, Lusch DP, Smucker TA, Wangui EE (2005) Multiple methods in the study of driving forces of land use and land cover change: a case study of SE Kajiado District, Kenya. Hum Ecol 33(6):763-794

Fratkin E (2008) Pastures Lost. Economies and the Transformation of Landscape 25:149.

Groom RJ, Western D (2013) Impact of land subdivision and sedentarization on wildlife in Kenyas's southern rangelands. Rangeland Ecol Manage 66(1):1-9

Kaimba GK, Njehia BK, Guliye AY (2011) Effects of cattle rustling and household characteristics on migration decisions and herd size amongst pastoralists in Baringo District, Kenya. Res Policy Pract 1:18

Kioko J, Kiringe JW, Seno S (2012) Impacts of livestock grazing on a savanna grassland in Kenya. J Arid Land 4(1):29-35

Kioko J, Okello MM (2010) Land use cover and environmental changes in a semiarid rangeland, Southern Kenya. J Geograp Region Plan 3(11):322-326

Kipkeu ML, Mwangi SW, Njogu J (2014) Community participation in wildlife conservation in Amboseli ecosystem, Kenya. J Environ Sci Toxicol Food Technol 8(4):68-75

Kirwa EC, Nyangito MM, Nyariki DM, Kimitei RK (2012) Effect of land use changes on adaptive strategies for smallholder agro-pastoralists in Kenya. Livestock Research for Rural Development, 24(8):2012.

Kristjanson PM, Radeny M, Nkedianye D, Kruska RL, Reid RS, Gichohi H, Atieno F, Sanford R (2002) Valuing alternative land-use options in the Kitengela wildlife dispersal area of Kenya. International Livestock Research Institute, Nairobi

Moyo B, Dube S, Moyo P (2013) Rangeland management and drought coping strategies for livestock farmers in the semi-arid savanna communal areas of Zimbabwe. J Hum Ecol 44(1):9-21

Msoffe FU, Kifugo SC, Said MY, Neselle MO, Van Gardingen P, Reid RS, De Leeuw $J$ (2011) Drivers and impacts of land-use change in the Maasai Steppe of northern Tanzania: an ecological, social and political analysis. J Land Use Sci 6(4):261-281

Nkedianye D, de Leeuw J, Ogutu JO, Said MY, Saidimu TL, Kifugo SC, Kaelo DS, Reid RS (2011) Mobility and livestock mortality in communally used pastoral areas: the impact of the 2005-2006 drought on livestock mortality in Maasailand. J Pastoralism 1(1):17

Noe C (2003). The dynamics of land use changes and their impacts on the wildlife corridor between Mt. Kilimanjaro and Amboseli National Park. LUCID project working paper 31

Nyamasyo SK, Kihima BO (2014) Changing land use patterns and their impacts on wild ungulates in Kimana wetland ecosystem, Kenya. Int J Biodivers

Nyariki DM, Mwang'ombe WA, Thompson DM (2009) Land-use change and livestock production challenges in an integrated system: the Masai-Mara ecosystem, Kenya. Journal of Human Ecology 26(3):163-173.

Okello MM (2012) The contraction of wildlife dispersal areas by human structures and activities in Mbirikani Group Ranch in the Amboseli Ecosystem, Kenya. International Journal of Biodiversity and Conservation 4(6):243-259.

Olson JM, Misana S, Campbell DJ, Mbonile M, Mugisha S (2004). A research framework to identify the root causes of land use change leading to land degradation and changing biodiversity of the land. LUCID project working paper 47

Opiyo FE, Mureithi SM, Ngugi RK (2011) The influence of water availability on pastoralist's resource use in Mwingi and Kitui districts in Kenya. Journal of Human Ecology 35(1):43-52.

Reda KT (2012) Pastoralism at crossroads: Changing features of climate, livelihood and social organization in East Africa. Glob J Hum Soc Sci Res 12(9-C)

Reid RS, Fernandes-Gimenez ME, Galvin KA (2014) Dynamics and resilience of rangelands and pastoral peoples around the globe. Annu Rev Environ Resour 39:217-242

Schilling J, Opiyo FEO, Scheffran J (2012) Raiding pastoral livelihoods: motives and effects of violent conflict in north-western Kenya. Res Pol Pract 2012 2:25

Tefera S (2014) Changes in Livestock Mobility and Grazing Pattern among the Hamer in Southwestern Ethiopia.

Tilahun M, Angassa A, Abebe A, Mengistu A (2016) Perception and attitude of pastoralists on the use and conservation of rangeland resources in Afar Region, Ethiopia. Ecol Process 5:18 
Western D (2007) A half a century of habitat change in Amboseli National Park, Kenya. Afr J Ecol 45(3):302-310

Western D, Groom R, Worden J (2009) The impact of subdivision and sedentarization of pastoral lands on wildlife in an African savanna ecosystem. Biol Conserv 142(11):2538-2546

Western D, Maitumo D (2004) Woodland loss and restoration in a savanna park: a 20-year experiment. Afr J Ecol 42(2):111-121

Western D, Mose VN, Worden J, Maitumo D (2015) Predicting extreme droughts in savannah Africa: a comparison of proxy and direct measures in detecting biomass fluctuations, trends and their causes. PLoS One 10(8):e0136516

Western D, Nightingale DLM (2003) Environmental change and the vulnerability of pastoralists to drought: a case study of the Maasai in Amboseli, Kenya. Africa Environmental Outlook Report. UNEP, Nairobi

Wilson RT (2003) Livestock production and farm animal genetic resources in the Usangu Wetland of the Southern Highlands of Tanzania. Livestock Research for Rural Development. Volume 15, Article \#2. http://www.Irrd.org//rrd15/1/ wils151.htm

\section{Submit your manuscript to a SpringerOpen ${ }^{\circ}$ journal and benefit from:}

- Convenient online submission

- Rigorous peer review

- Open access: articles freely available online

- High visibility within the field

- Retaining the copyright to your article

Submit your next manuscript at $\gg$ springeropen.com 